\title{
Analysis and Evaluation of Cassava Starch-Based Biodegradable Trays as an Alternative Packaging to Fresh Strawberry (Fragaria ananassa cv San Andreas)
}

\author{
Marina Baratter ${ }^{1}$, Eduarda Francine Weschenlfelder ${ }^{1}$, Fernanda Stoffel ${ }^{2,}$, , Mara Zeni ${ }^{2}$, \\ Luciani Tatsch Piemolini-Barreto ${ }^{1}$ \\ ${ }^{1}$ Centre of Exact Science \& Technology, Department of Food Engineering, University of Caxias do Sul, Caxias do Sul, Brazil \\ ${ }^{2}$ Centre of Exact Science \& Technology, Research Laboratory of Materials Chemistry, University of Caxias do Sul, Caxias do Sul, Brazil
}

Email address:

mbaratter@gmail.com (M. Baratter), efweschenfelder@ucs.br (E. F. Weschenfelder), fernanda.stoffel@hotmail.com (F. Stoffel), mzandrar@ucs.br (M. Zeni), 1tbarre@ucs.br (L. T. Piemolini-Barreto)

*Corresponding author

\section{To cite this article:}

Marina Baratter, Eduarda Francine Weschenlfelder, Fernanda Stoffel, Mara Zeni, Luciani Tatsch Piemolini-Barreto. Analysis and Evaluation of Cassava Starch-Based Biodegradable Trays as an Alternative Packaging to Fresh Strawberry (Fragaria ananassa cv San Andreas). American Journal of Polymer Science and Technology. Vol. 3, No. 4, 2017, pp. 76-81. doi: 10.11648/j.ajpst.20170304.14

Received: May 21, 2017; Accepted: June 26, 2017; Published: July 25, 2017

\begin{abstract}
In this study, biodegradable cassava starch/poly (vinyl alcohol) (PVA) trays with and without poly (lactic acid) (PLA) coating were evaluated as possible substitutes for expanded poly (styrene) (EPS) trays in strawberry packaging. The parameters evaluated were physical and chemical parameters of $\mathrm{pH}$, soluble solids and titratable acidity for strawberries, strawberry and trays moisture content and the mass loss of the systems. In addition, the amount of molds and yeasts was determined in both strawberries and trays. None of the trays used in this study caused changes in the physical and chemical parameters of the strawberries. The molds and yeasts growth was higher in the strawberries packed in EPS compared with the other packaging. The trays with PLA coating and the EPS trays had statistically equal mass loss. The PLA coating applied on cassava starch-based trays was efficient as moisture absorption barrier.
\end{abstract}

Keywords: Cassava Starch, Biodegradable Packaging, Trays

\section{Introduction}

Packaging has a key role in the food industry because they act as a barrier against the factors responsible for chemical, physical and microbiological deterioration of food. In addition to store, conserve and maintain the quality and safety of food [1]. Polymers from non-renewable sources are used in many packaging applications because they are resistant, durable, easy to process and have low cost. However, this kind of materials usually brings serious problems to the environment due to its difficulty of decomposition [2].

One alternative to reduce the environmental impact is biodegradable packaging obtained from renewable sources such as starch and cellulose [3, 4]. The most important factor that differentiates biodegradable packaging of nonbiodegradable packaging is the time of degradation by microorganisms when disposed in soil [5].

Among the vegetable raw materials used in the production of packaging, starch has received special attention for being an abundant resource, derived from renewable sources, low cost material, it has the potential of complete degradation after use, and the property to form films and foams [3, 6, 7].

One of the greatest sources of starch is cassava (Manihot esculenta crantz), which has $33 \%$ of starch in its composition and approximately $83 \%$ of this starch is constituted of amylopectin and approximately $17 \%$ of amylose. Cassava is an abundant and economic important raw material in Brazil $[4,7,8]$.

Starch foams are considered promising for technological applications, but they show poor mechanical properties and low resistance to water when compared to petroleum-based packaging. Some biodegradable polymers have been used as additives to improve the sensitivity to moisture and the mechanical properties of starch-based foams. According to 
Debiagi [2, 7], the addition of PVA shows an increase in resistance to direct contact with water in starch foams.

Use of a coating method or surface thin films deposition to improve packaging water resistance properties is of great interest [9]. Thus, for minimize water uptake by starch foams, studies report the application of coatings or hydrophobic materials impregnation of to them. Among materials used as coatings, poly (lactic acid) (PLA) has been extensively studied [10]. PLA can be used as a coating material because it is biodegradable and safe for use as a food contact material. Furthermore, presents resistance to moisture and barrier properties against gases and water vapor, properties considered as requirements for food packaging materials [11].

Applications of biodegradable starch-based packaging in food have been studied and evaluated for some time. Some authors concluded that they can be used for packaging of food with low water activity $[12,15]$. In this context, the present study had the objective of evaluating the applicability of biodegradable cassava starch/PVA trays with and without PLA coating in strawberry packaging; since it is a fruit with high moisture content, and comparing to the EPS trays.

\section{Experimental}

\subsection{Materials}

In this study, strawberries (Fragaria ananassa cv San Andreas) harvested in August in the beginning of 2014 season and EPS trays donated by Granja Andreazza (Caxias do Sul, RS, Brazil) were used. The biodegradable cassava starch-based trays were produced in the Laboratory of Research in Materials Chemistry of University of Caxias do Sul by thermal expansion of a starch suspension in water, according Stoffel et al. (2015) [14], that was prepared with PVA addition at $5.0 \%(\mathrm{w} / \mathrm{w}$, on starch weight $), 1 \%(\mathrm{w} / \mathrm{w})$ magnesium stearate to prevent the starch foam from sticking to the mold and $1 \%(\mathrm{w} / \mathrm{w})$ guar gum, to prevent the solid from separating in suspension. All components were mechanically mixed for $20 \mathrm{~min}, 10-12 \mathrm{~g}$ of starch suspension was homogeneously layered into a metallic mold $(80 \mathrm{~mm}$ long, $80 \mathrm{~mm}$ wide and $2 \mathrm{~mm}$ high). Thermo pressing was performed with a hydraulic at $170^{\circ} \mathrm{C}$ for $5 \mathrm{~min}$, and $2 \mathrm{t}$ of pressure. The molds were removed from the hydraulic press. After cooling, the PLA coating, at $15 \%(\mathrm{w} / \mathrm{v})$, was applied by immersion method based on Schimidt e Laurindo (2009) [15].

\subsection{Sampling Preparation}

In the biodegradable cassava starch-based trays with and without PLA coating and the EPS trays, $80 \mathrm{~g}$ of strawberry randomly selected, were stored in triplicate, with dimensions of $140 \times 140 \times 15 \times 2 \mathrm{~mm}$. The trays were wrapped in polyvinyl chloride (PVC) film and stored at low temperature in refrigerator $\left(5^{\circ} \mathrm{C}\right)$ for nine days (Figure 1). The samples of strawberries and trays were analyzed at times of $0,3,6$ and 9 days of storage.

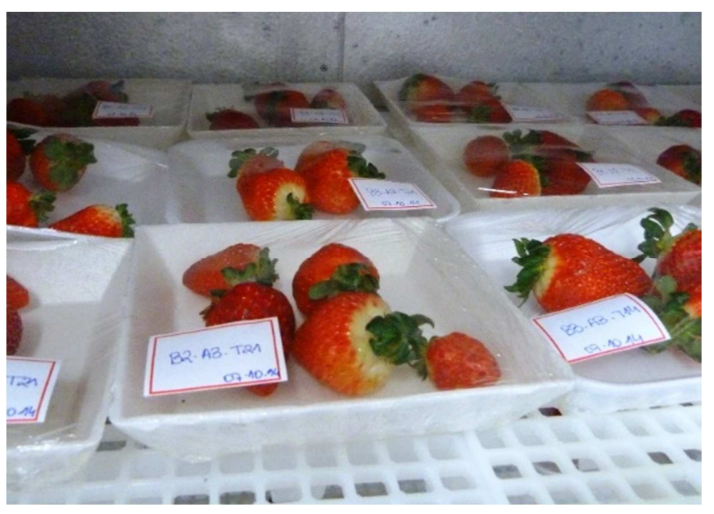

Figure 1. Strawberry packed in biodegradable cassava starch-based trays with and without PLA coating and in the EPS trays, stored at $5^{\circ} \mathrm{C}$ in refrigerator:

\subsection{Physical and Chemical Analysis}

\subsubsection{Determination of $\mathrm{pH}$}

A previously calibrated $\mathrm{pH}$ meter (model DM-2, Digimed, Brazil) was used to determine the $\mathrm{pH}$ of the strawberries according to AOAC recommended methodology [16].

\subsubsection{Determination of Titratable Acidity}

The titratable acidity of the strawberries was determined according to the methodology described by AOAC [16] by titration with $0.1 \mathrm{~mol}$. L-1 $\mathrm{NaOH}$ solution, with the indicator of Bromothymol blue $0.1 \%$. The result of the titratable acidity was obtained as shown in Equation 1.

$$
m g \text { citric acid } / 100 g=\left(\frac{100 v f}{p c}\right) 0.0075
$$

Where: $v=$ volume of $\mathrm{NaOH} 0.1 \mathrm{~mol} . \mathrm{L}^{-1}$ solution used in the titration $(\mathrm{mL}) ; f=$ factor of the $\mathrm{NaOH} 0.1$ mol. $\mathrm{L}^{-1}$ solution; $p=$ weight of the sample used in the titration $(\mathrm{g}) ; c$ $=$ correction to the $\mathrm{NaOH} 0.1 \mathrm{~mol}$. $\mathrm{L}^{-1}$ solution.

\subsubsection{Determination of Soluble Solids}

The amount of soluble solids ( ${ }^{\circ}$ Brix) of the strawberries was estimated by refractometer (model HI 96801, HANNA, Romania) according to the methodology described by AOAC [16].

\subsubsection{Determination of Moisture Content}

The moisture content was determined by gravimetry using an oven as drying equipment, according to the AOAC method [16]. The moisture content was calculated according to Equation 2:

$$
\% \text { moisture }=\left(\frac{\mathrm{mi}-\mathrm{mf}}{\mathrm{mi}}\right) 100
$$

Where: $\mathrm{m}_{\mathrm{i}}=$ initial weight of the sample $(\mathrm{g}) ; \mathrm{m}_{\mathrm{f}}=$ final weight of the sample $(\mathrm{g})$.

\subsubsection{Determination of Moisture Loss of the System (Tray + Strawberries)}

The moisture loss of the system was analyzed using the difference in weight of the trays and strawberries at times of 0, 3, 6 and 9 days, the results were expressed in percentage. 


\subsection{Microbiological Analysis}

The microbiological analyses were performed by counting the molds and yeasts of strawberries and trays at 0, 3, 6 and 9 days of storage, according to the methodology adapted from Alexandre et al. [17]. Samples of $25 \mathrm{~g}$ were aseptically weighed and placed in sterilized plastic bags containing 225 $\mathrm{mL}$ of saline peptone solution $1 \%(\mathrm{w} / \mathrm{v})$ and homogenized in Stomacher (England), for $180 \mathrm{~s}$. Decimal dilutions (10-1 and 10-2) were conducted. The dilution samples were inoculated into petri dishes containing 15 to $20 \mathrm{~mL}$ of Potato Agar Dextrose (PDA) medium (Merck), and incubated in oven at $25^{\circ} \mathrm{C}$ during 5 to 7 days. The analyses were carried out in triplicate for each time of storage.

\subsection{Statistical Analysis}

The statistical analyses were conducted using analysis of variance (ANOVA) and Tukey's mean test with significance level set at 5\%, for this purpose it was used the GraphPad Prism software.

\section{Resultus and Discussion}

\subsection{Physical and Chemical Analysis}

\subsection{1. $\mathrm{pH}$}

Table 1 shows the $\mathrm{pH}$ values of the strawberries packed in cassava starch/PVA trays with and without PLA coating and EPS trays, during the period of 9 days.

Table 1. Values of pH of strawberries packed in starch-based trays and EPS trays and stored at $5^{\circ} \mathrm{C}$ for 9 days.

\begin{tabular}{|c|c|c|c|}
\hline \multirow{2}{*}{$\begin{array}{l}\text { Time } \\
\text { (days) }\end{array}$} & \multicolumn{3}{|l|}{$\mathbf{p H}$} \\
\hline & PVA/Starch tray & PVA/PLA/Starch tray & EPS tray \\
\hline 0 & $3.47 \pm 0.03 \mathrm{a}$ & $3.47 \pm 0.03^{\mathrm{a}}$ & $3.47 \pm 0.03 a$ \\
\hline 3 & $3.32 \pm 0.06 \mathrm{a}$ & $3.40 \pm 0.01^{\mathrm{a}}$ & $3.48 \pm 0.01 \mathrm{a}$ \\
\hline 6 & $3.46 \pm 0.08 \mathrm{a}$ & $3.50 \pm 0.08^{\mathrm{a}}$ & $3.75 \pm 0.57 \mathrm{a}$ \\
\hline 9 & $3.63 \pm 0.15 a$ & $3.72 \pm 0.05^{\mathrm{a}}$ & $3.62 \pm 0.10 \mathrm{a}$ \\
\hline
\end{tabular}

Values were determined in triplicate. Equal letters indicate no significant difference at $5 \%(\mathrm{p}<0.05)$ in the evaluated parameter.
During the storage period, it was not observed any significant alterations in the $\mathrm{pH}$ of the samples. The values varied from 3.32 to 3.63 for the cassava starch-based trays, without PLA coating, 3.40 to 3.72 for the cassava starchbased trays with PLA coating, and values from 3.47 to 3.75 for the EPS trays.

Small non-significant variations of $\mathrm{pH}$ might have resulted from the buffering effect of the presence of organic acids and their salts simultaneously, which would prevent that an increase in titratable acidity could alter the $\mathrm{pH}$ values significantly. This was also evidenced by Fakhouri and Grosso [18] who studied the effect of edible coatings in the shelf life of fresh guavas kept under refrigeration.

The range of values found in this study are consistent with results obtained by Alexander et al. [17] $\mathrm{pH}$ values from 3.31 to 3.79 for cv. Camarosa strawberries. De Bruijn and Bórquez [19] in their study, obtained $\mathrm{pH}$ results for San Andreas strawberries from 3.45 to 3.67. Based on the results it was observed that the EPS packaging and the biodegradable starch-based packaging did not influence the $\mathrm{pH}$ of the strawberries.

\subsubsection{Titratable Acidity}

According to Moraes et al. [20] generally titratable acidity of fruits decreases significantly during the storage period because the organic acids tend to decrease during ripening, due to its use as substrate for respiration.

Table 2 shows the titratable acidity values measured in the strawberry samples. It can be noticed a decrease in titratable acidity values over storage time for strawberries stored in three types of packaging.

Analysis of titratable acidity made by Velickova et al. [21] in strawberries cv. Camarosa wrapped in edible film of chitosan and beeswax and stored for 7 days showed significant reduction in the contents of organic acids in the samples analyzed.

Table 2. Titratable acidity values of strawberries packed in starch-based and EPS trays, stored at $5^{\circ} \mathrm{C}$ for 9 days.

\begin{tabular}{llll}
\hline \multirow{2}{*}{ Time (days) } & \multicolumn{2}{l}{ Titratable acidity $\left(\mathbf{m g}\right.$ of citric acid.100 $\left.\mathbf{g}^{\mathbf{- 1}}\right)$} & EPS tray \\
\cline { 2 - 4 } & PVA/Starch tray & PVA/PLA/Starch tray & $0.88 \pm 0.05 \mathrm{a}$ \\
\hline 0 & $0.88 \pm 0.05 \mathrm{a}$ & $0.88 \pm 0.05 \mathrm{a}$ & $0.74 \pm 0.05 \mathrm{~b}$ \\
3 & $0.63 \pm 0.01 \mathrm{c}$ & $0.76 \pm 0.05 \mathrm{~b}$ & $0.63 \pm 0.04 \mathrm{c}$ \\
6 & $0.41 \pm 0.03 \mathrm{e}$ & $0.58 \pm 0.03 \mathrm{~d}$ & $0.37 \pm 0.06 \mathrm{e}$ \\
9
\end{tabular}

Values were determined in triplicate. Equal letters indicate no significant difference at $5 \%(\mathrm{p}<0.05)$ in the evaluated parameter.

Moraes et al. [20] studied the titrable acidity of strawberries stored in controlled atmosphere and compared with strawberries stored in ambient atmosphere. For strawberries stored in ambient atmosphere, the found titratable acidity values decreased from 0.60 at 0 days of storage to 0.55 at 7 days of storage, these values are consistent with the results found in this study.

\subsubsection{Soluble Solids}

According to Resende et al. [22] due to the preference of the consumer market for sweet fruit, soluble solids content is a characteristic of interest for fruits commercialized fresh.

The soluble solids contents expressed in ${ }^{\circ}$ Brix of the strawberry samples stored in three types of packaging for the period of nine days are showed in Table 3. The results show, 
for all the samples, a reduction in the soluble solids values during the storage period, regardless of the type of tray in which the sample was stored.

Aday and Caner [23] studied the increase in shelf life of cv. Camarosa strawberries stored in PLA packaging containing oxygen absorbers, they found that the storage period of the strawberries affected significantly the soluble solids content of the fruit, with a decrease in the values during the storage period. Gol et al. [24] also observed a decrease in soluble solids during the storage period of $\mathrm{cv}$. Camarosa strawberries wrapped in edible film of chitosan. According to Yamashita et al. [25] sugar is used in the fruit during the storage time as a source of energy to maintain the metabolic activity, which causes a decrease in soluble solids.

Table 3. Soluble solids content ( ${ }^{\circ}$ Brix) of strawberries packed in starchbased and EPS trays, stored at $5^{\circ} \mathrm{C}$ for 9 days.

\begin{tabular}{llll}
\hline \multirow{2}{*}{$\begin{array}{l}\text { Time } \\
\text { (days) }\end{array}$} & \multicolumn{3}{l}{ Soluble Solids Content $\left({ }^{\circ}\right.$ Brix) } \\
\cline { 2 - 4 } & PVA/Starch tray & PVA/PLA/Starch tray & EPS tray \\
\hline 0 & $8.10 \pm 0.20 \mathrm{a}$ & $8.10 \pm 0.20 \mathrm{a}$ & $8.10 \pm 0.20 \mathrm{a}$ \\
3 & $6.60 \pm 0.26 \mathrm{~b}$ & $6.82 \pm 0.10 \mathrm{~b}$ & $6.55 \pm 0.57 \mathrm{~b}$ \\
6 & $6.80 \pm 0.36 \mathrm{~b}$ & $6.63 \pm 0.45 \mathrm{~b}$ & $6.93 \pm 0.26 \mathrm{~b}$ \\
9 & $6.68 \pm 0.50 \mathrm{~b}$ & $5.60 \pm 0.18 \mathrm{c}$ & $5.73 \pm 0.32 \mathrm{bc}$ \\
\hline
\end{tabular}

Values were determined in triplicate. Equal letters indicate no significant difference at $5 \%(\mathrm{p}<0.05)$ in the evaluated parameter.

The results of soluble solids found for the strawberries at time 0 days for all types of packaging differ statistically from the other results showing that at time 0 days the strawberries were sweeter than during storage. According to Françoso et al. [26] the soluble solids content gives an indication of the amount of existing sugars in the fruit. In the storage times of 3 and 6 days the results of soluble solids for strawberries stored in all types of packaging are not statistically different and also does not differentiate when compared to strawberries stored in starch-based tray without coating and EPS tray in the time of 9 days. The strawberries stored in starch-based trays with PLA coating and EPS trays in the time of 9 days are statistically equal.

The packaging, regardless of the material used, did not have influence on the reduction of soluble solids, since the values of soluble solids at the end of storage time were statistically equal.

In their study, Bruijn and Bórquez [19] found values of soluble solids for fresh strawberries between 7.19 and 8.81 Brix and Françoso et al. [26] obtained results in the range from 7.0 to 9.5 Brix.

\subsubsection{Moisture}

Table 4 shows the moisture content values for strawberries and packaging.

In the beginning of the storage time, the strawberries had about $93 \%$ of moisture, and at the end of the storage period, the moisture decreased in the samples stored in the three types of packaging. The sample with the highest moisture loss was the strawberry stored in the cassava starch-based tray without PLA coating with a decrease of $56.3 \%$, followed by strawberry samples stored in EPS trays and cassava starch-based trays with PLA coating, with values of $55.6 \%$ and $54.4 \%$, respectively.

At the end of the storage period all the trays had an increase in moisture content, and the cassava starch-based tray without coating showed the higher moisture content (55.5\%). The cassava starch-based tray with PLA coating showed a value of $50.5 \%$ moisture content, showing that the PLA coating on cassava starch trays was effective in controlling the moisture content of the tray due to the hydrophobic characteristic of PLA [27].

The moisture loss of the strawberry samples, as well as the increase of moisture in the trays can be related to the water vapor permeability of each package. According to Clasen et al. [6], polymers derived from natural sources have high permeability to water vapor compared to the polymers of petrochemical origin.

Table 4. Moisture content of strawberries stored in starch-based and EPS trays, at $5^{\circ} \mathrm{C}$ for 9 days.

\begin{tabular}{|c|c|c|c|c|c|}
\hline \multirow{3}{*}{ Time (days) } & \multicolumn{5}{|c|}{ Moisture content (\%) } \\
\hline & \multicolumn{2}{|c|}{ PVA/Starch tray } & \multicolumn{2}{|c|}{ PVA/PLA/Starch tray } & \multirow{2}{*}{$\begin{array}{l}\text { EPS tray } \\
\text { Strawberry }\end{array}$} \\
\hline & Tray & Strawberry & Tray & Strawberry & \\
\hline 0 & $11.55 \pm 1.10 \mathrm{~g}$ & $93.03 \pm 2.63^{a}$ & $12.75 \pm 0.18 \mathrm{~g}$ & $92.51 \pm 2.58 \mathrm{a}$ & $93.50 \pm 1.70 \mathrm{a}$ \\
\hline 3 & $42.87 \pm 0.60 \mathrm{ef}$ & $59.72 \pm 0.19 b$ & $38.61 \pm 2.27 f$ & $60.34 \pm 0.90 b$ & $58.24 \pm 0.40 b$ \\
\hline 6 & $50.85 \pm 0.09 d$ & $47.21 \pm 2.11 \mathrm{de}$ & $47.27 \pm 2.48 \mathrm{de}$ & $45.98 \pm 3.48 \mathrm{de}$ & $44.25 \pm 2.21 \mathrm{e}$ \\
\hline 9 & $55.55 \pm 0.97 \mathrm{c}$ & $40.67 \pm 0.51 \mathrm{f}$ & $50.52 \pm 0.82 d$ & $42.16 \pm 0.68 \mathrm{ef}$ & $41.53 \pm 0.33 f$ \\
\hline
\end{tabular}

Values were determined in triplicate. Equal letters indicate no significant difference at $5 \%(\mathrm{p}<0.05)$ in the evaluated parameter.

Schmidt and Laurindo [15], in a study to develop packaging from renewable sources based in cassava starch and cellulosic fibers, found that the hygroscopic property of starch-based packaging can be improved by sealing with PVC films. Rhim et al. [10] suggest the use of PLA films for coating the packaging in contact with food because of its low permeability to water vapor, associated with the hydrophobic characteristics of this material.

According to Soares et al. [9], biodegradable polymers such as PLA have been tested in order to improve the properties of starch-based packaging such as hygroscopic character and high permeability to water vapor. In this study in obtaining and assessment of physical and chemical properties of PLA laminates, thermoplastic starch coated with cross-linked chitosan, the author concluded that the permeability to water vapor decreased $33 \%$ in packaging with coating when compared to packaging without coating.

The moisture analyses were not carried out for the EPS trays because, according to Chen et al. [28], EPS is not a hygroscopic material and it offers high resistance to water 
vapor permeability, giving it also a defense to the action of water and moisture, keeping unchanged its properties.

\subsubsection{Determination of Moisture Loss of the System (Tray + Strawberries)}

The results of mass loss for the systems are shown in Table 5. There was a mass loss for the three systems analyzed, but higher for the EPS trays and cassava starch-based trays with PLA coating with mass loss values of $12.0 \%$ and $12.5 \%$, respectively, values that did not differ statistically. The starch-based trays without coating showed the lowest weight loss $(8.4 \%)$ at the end of the storage period.

Table 5. Loss mass of the system (tray+strawberries) during the storage period of 9 days at $5^{\circ} \mathrm{C}$.

\begin{tabular}{llll}
\hline \multirow{2}{*}{$\begin{array}{l}\text { Time } \\
\text { (days) }\end{array}$} & \multicolumn{3}{l}{ Mass loss (moisture) of the system (\%) } \\
\cline { 2 - 4 } & $\begin{array}{l}\text { PVA/Starch } \\
\text { tray }\end{array}$ & $\begin{array}{l}\text { PVA/PLA/Starch } \\
\text { tray }\end{array}$ & EPS tray \\
\hline 0 & $0.00 \pm 0.00 \mathrm{f}$ & $0.00 \pm 0.00 \mathrm{f}$ & $0.00 \pm 0.00 \mathrm{f}$ \\
3 & $1.88 \pm 0.25 \mathrm{e}$ & $6.17 \pm 0.15 \mathrm{~d}$ & $5.55 \pm 0.58 \mathrm{~d}$ \\
6 & $5.96 \pm 0.56 \mathrm{~d}$ & $11.53 \pm 0.52 \mathrm{ab}$ & $10.87 \pm 0.20 \mathrm{~b}$ \\
9 & $8.36 \pm 0.18 \mathrm{c}$ & $12.48 \pm 0.12 \mathrm{a}$ & $11.96 \pm 0.50 \mathrm{a}$ \\
\hline
\end{tabular}

Values were determined in triplicate. Equal letters indicate no significant difference at $5 \%(\mathrm{p}<0.05)$ in the evaluated parameter.

Comparing the results of moisture content and mass loss of the system, it was possible to affirm that the starch-based trays without coating system had the highest result of moisture for the tray and the lowest result of moisture for the strawberries at the end of the storage period. This was the system that showed the lowest mass loss, which indicates that the moisture of the strawberries was absorbed by the tray during storage. The cassava starch-based trays with PLA coating that showed lower moisture for the tray and higher values for strawberries related to mass loss of the system were the trays with the highest mass loss, which shows that they absorbed less water from the system.

The EPS trays, because they do not absorb water, also showed high mass loss values, which did not differ statistically from the results of mass loss of moisture in the starch-based trays with PLA coating.

Olivato et al. [29] studied the effect of biodegradable starch-based packaging in the processed cheese storage compared with conventional polypropylene packaging, and found that the mass loss of the samples was lower in polypropylene packaging and higher in starch-based packaging. They concluded that the difference between the starch-based and the conventional packaging was mainly due to their difference in permeability to water vapor.

\subsection{Microbiological Analysis}

\section{Molds and Yeasts}

Table 6 shows the values of molds and yeasts found in the strawberries and the packaging in which they were stored.

Table 6. Values of yeasts and molds (CFU/g) for cassava starch-based trays, EPS trays and strawberries stored in three types of trays at $5^{\circ} \mathrm{C}$ for 9 days.

\begin{tabular}{lllll}
\hline Time (days) & PVA/Starch tray & & PVA/PLA/Starch tray & Strawberries \\
\hline & Tray & Strawberries & Tray & Tray \\
\hline 0 & $<1.5 \times 10^{3}$ & $2.25 \times 10^{3}$ & negative & $2.25 \times 10^{3}$ \\
3 & $<1.5 \times 10^{3}$ & $2.4 \times 10^{4}$ & $<1.5 \times 10^{3}$ & $3.3 \times 10^{3}$ \\
6 & $2.8 \times 10^{3}$ & $5.5 \times 10^{4}$ & $<1.5 \times 10^{3}$ & n.e \\
9 & $3.375 \times 10^{3}$ & $9.8 \times 10^{4}$ & $2.6 \times 10^{3}$ & n.e \\
\hline
\end{tabular}

Françoso et al. [26] cite, among other factors, the deterioration caused by fungi as the main contributor to the decrease in the shelf life of strawberry.

There was an increase in the number of molds and yeasts for all samples of strawberries and trays analyzed during the storage period, whereas the sample that obtained the most expressive molds and yeasts count was the sample stored in the EPS packaging at times of 6 and 9 days, which resulted in uncountable values of this microbiological parameter.

\section{Conclusions}

The results of this study demonstrate the potential application of cassava starch-based packaging with PLA coating as a substitute for EPS packaging in strawberries storage.

The PLA coating was efficient to improve the hygroscopic characteristics of cassava starch-based trays because the coated cassava starch-based trays showed statistically equal values of moisture content and mass loss to EPS trays, parameters considered critical for biodegradable starch-based packaging due to its high capacity of water absorption. However, further studies are needed to evaluate the performance of packaging systems during transport conditions, such as mechanical stresses and temperature changes.

\section{References}

[1] V. Siracusa, P. Rocculi, S. Romani, and M. D. Rosa, "Biodegradable Polymers for food packaging: a review", Trends Food Science and Technology, vol. 19, pp. 634-643, 2008.

[2] F. Debiagi, R. K. T. Kobayashi, G. Nakazato, L. A. Panagio and S. Mali, "Biodegradable active packaging based on cassava bagasse, polyninyl alcohol and essential oil", Industrial Crops and Products, vol. 52, pp. 664-670, 2014.

[3] L. G. Carr, D. F. Parra, P. Ponce, A. B. Lugão and P. M. Buchler, "Influence of Fibers on the Mechanical Properties of Cassava Starch Foams", Journal of Polymers and the Environment, vol. 14, pp. 179-183, 2006.

[4] P. R. Salgado, V. C. Schmidt, S. E. M. Ortiz, A. N. Mauri and J. B. Laurindo, "Biodegradable foams based on cassava starch, sunflower protein and cellulose fibers obtained by baking process", Journal of Food Engineering, vol. 85, pp. 435-443, 2008. 
[5] Z. Abbasi, "Water resistence, weight loss and enzymatic degradation of blends starch/polyvinyl alcohol containing $\mathrm{SiO} 2$ nanoparticle", Journal of Taiwan Institute of Chemical Engineers, vol. 43, pp. 264-268, 2012.

[6] S. H. Clasen, C. M. O. Müller and A. T. N. Pires, "Maleic Anhydride as a Compatibilizer and Plasticizer in TPS/PLA Blends", Journal of the Brazilian Chemical Society, vol. 26, pp. 1583-1590, 2014.

[7] F. Debiagi, B. M. Marim and S. Mali, "Properties of Cassava Bagasse and Polyvinyl Alcohol Biodegradable Foams", Journal of Polymers and the Environment, vol. 23, pp. 269276, 2015.

[8] A. E. S. Vercelheze, F. M. Fakhouri, L. H. Dall'Antônia, A. Urbano, E. Y. Youssef, F. Yamashita and S. Mali, "Properties of baked foams based on cassava starch, sugarcane bagasse fibers ans montmorillonite" Carbohydrate Polymers, vol. 87, pp. $1302-1310,2012$.

[9] F. C. Soares, F. Yamashita, C. M. O. Müller and A. T. N. Pires, "Thermoplastic starch/poly(lactic acid) sheets coated with cross-linked chitosan", Polymer Testing, vol. 32, pp. 94 - 98, 2013.

[10] J. Rhim, J. Lee, and S. Hong, "Increase in Water Resistance of Paperboard by coating with Poly(lactide)", Packaging Technology and Science, vol. 20, pp. 393 - 402, 2007.

[11] K. Khwaldia, E. Arab-Tehrany, S. Desobry, "Biopolymer coatings on paper packaging materials", Food Science and Food, vol. 9, pp. 82-91, 2010.

[12] F. Debiagi, S. Mali, M. V. E. Grossmann and F. Yamashita, "Biodegradable foams based on starch, polyvinyl alcohol, chitosan and sugarcane fibers obtained by extrusion", Brazilian Archives of Biology and Technology, vol. 54, pp. 1043-1052, 2011.

[13] L. R. P. F. Mello and S. Mali, "Use of malt bagasse to produce biodegradable baked foams made from cassava starch", Industrial Crops and Products, vol. 55, pp. 187-193, 2014.

[14] F. Stoffel, L. Piemilini-Barreto, M. Zeni, "Preparation of cassava starch-based trays with glycerol, sorbitol and poly (vinyl alcohol): properties and influence for use as food packaging", Research \& Reviews: Journal of Food Science and Technology, vol. 4, pp. 1 8, 2015.

[15] V. C. R. Schmidt and J. B. Laurindo, "Characterization of Foams Obtained from Cassava Starch, Cellulose Fibres and Dolomitic Limestone by a Thermopressing Process", Brazilian Archives of Biology and Technology, vol. 53, pp. 185-192, 2010 .

[16] AOAC, Association of Official Analytical Chemists, Official Methods of Analysis, Washington D., 1998.

[17] E. M. C. Alexandre, T. R. S. Brandão and C. L. M. Silva, "Efficacy of non-thermal Technologies and sanitizer on microbial load reduction and quality retention of strawberries", Journal of Food Engineering, vol. 108, pp. 417426, 2012.

[18] F. M. Fakhouri and C. Grosso, "Effect of Edible Coatings on the Shelf Life of in natura Guava (Psidium guajava L.) Stored Under Refrigeration", Brazilian Journal of Food Technology, vol. 6, pp. 203-211, 2003.

[19] J. De Bruijn and R. Bórquez, "Quality retention in strawberries dried by emerging dehydration methods", Food Research International, vol. 63, pp. 42-18, 2014.

[20] I. V. M. D. Moares, S. A. Cenci, B. C. Benedetti, A. M. G. N Mamede, A. G. Soares, and H. T. G. Barboza, "Physical and Chemical characteristics of minimally processed strawberries stored under refrigeration and controled atmospheres", Food Science and Technology, vol. 28, pp. 274-281, 2008.

[21] E. Velickova, E. Winkelhausen, S. Kuzmanova, V. D. Alvez, and M. Moldão-Martins, "Impact of chitosan-besswax edible coating on the quality of fresh strawberries (Fragaria ananassa cv Camarosa) under commercial storage conditions", LWT Food Science and Technology, vol. 52, pp. 80-92, 2013.

[22] J. T. V. Resende, R. G. F. Morales, M. V. Faria, A. L. L. Rissini, L. K. P. Camargo and C. K. Camargo, "Produtividade e teor de sólidos solúveis de frutos de cultivares de morangueiro em ambiente protegido", Horticultura Brasileira, vol. 28 , pp. 185-189, 2010.

[23] M. S. Aday and C. Caner, "The shelf life extension of fresh strawberries using a oxygen absorber in the biobased package", LWT - Food Science and Technology, vol. 52, pp. 102-109, 2013.

[24] N. B. Gol, P. R. Patel, and T. V. Ramana Rao, "Improvement of quality and shelf life of strawberries with edible coatings enriched with chitosan", Postharvest Biology and Technology, vol. 85 , pp. 185-195, 2013.

[25] F. Yamashita, G. F. Veiga, M. T. Benassi and S. R. Roberto, "Strawberries packaged with Polyvinyl Cloride (PVC) film", Semina: Ciencias Agrarárias, vol. 27, pp. 429-436, 2006.

[26] I. L. Françoso, M. A. L. Couto, S. G. Canniatti - Brazaca and V. Arthur, "Physical-chemical alterations in irradiated and stored strawberries (Fragaria anassa Duch.)", Food Science and Technolology, vol. 28, pp. 614-619, 2008.

[27] L. Qin, J. Qiu, M. Liu, S. Ding, L. Shao, S. Lü, G. Zhang, Y. Zhao, and $\mathrm{X}$. Fu, "Mechanical and thermal properties of poly(lactic acid) composites with rice straw fiber modified by poly(butyl acrylate)" Chemical Engineering Journal, vol. 166, pp. 772-228, 2011.

[28] W. Chen, H. Hao, D. Hughes, Y. Shi, J. Cui and Z. Li, "Static and dynamic mechanical properties of expanded polystyrene", Materials \&. Design, vol. 69, pp. 170-180, 2015.

[29] J. B. Olivato, S. Mali and M. V. E. Grossmann, "Effect of biodegradable starch packing on storage of processed cheese". Semina: Ciencia Agraria, vol. 27, pp. 81-88, 2006. 